\title{
ANALYSIS OF REBOUNDED BALLS IN A TEAM HANDBALL MATCH
}

\author{
Ante Burger ${ }^{1}$, Nenad Rogulj $^{1}$, Nikola Foretić ${ }^{1}$, and Marijana Čavala ${ }^{1}$ \\ ${ }^{1}$ Faculty of Kinesiology, University of Split, Croatia
}

\section{SUMMARY}

We have analysed fifteen matches played by the male Croatian national handball team at the World Championship in Tunisia in 2005 and those played at the European Championship in Austria in 2010. The research has been conducted with the purpose of establishing the frequency of shooting from certain zones, i.e. from the attacking positions, the frequency of rebounded balls off the goal keeper or off the goal frame, as well as establishing where or who to the performed shots rebound. The field for the position game was divided into five zones: the left wing player, the left back player, the middle back player, the right back player and the right wing player. The mentioned zones also represent the rebounding zones. The results have shown that most shots were performed from the central zone, while the frequency of shooting from other zones was mostly equally disposed. The average number of the balls rebounded off the goal keeper or the goal frame is 17.6 balls. In $71 \%$ of the cases, the rebounded balls end in the possession of defence players which is the consequence of their close position in relation to the ball. The biggest number of rebounded balls (40\%) returns to the central zone. By the $\chi^{2}$ test we established that the largest number of shots performed from a certain zone rebounds in the same zone, or, in rare cases, in the nearby zone. This greatly depends on the shooting angle, which is mostly in a straight line in relation to the goal, and on the goal keeper's position in relation to the ball. The research implies the need for practising this game segment during handball training by the means of specific and situation training exercises.

Key Words: rebounded ball, handball game, shot on goal, goal keeper.

\section{INTRODUCTION}

Handball game consists of four phases: position defence, position attack, transition defence and transition attack. A faster transition from one phase to another enables a faster and more attractive game with more opportunities to score. Most handball experts support this type of approach to the game (Pokrajac, 2008; Rogulj, 2000a). The quality of transferring from the position defence into transition attack depends on the speed of returning the ball back in the game by the goal keeper. The transition attack starts when the opposing team makes a technical mistake or does not score when shooting on goal. The shot on goal can be directed to the goal frame or outside it. If the shot was directed towards the goal frame, the ball rebounds from the goal keeper and most frequently, due to the shooting speed of the ball
(Gorostiaga, Granados, Ibáñez, \& Izquierdo, 2005; Hermassi, Chelly, Fathloun, \& Shephard, 2010), does not remain in his possession, but rebounds behind the base line of the court or returns from the goal keeper's area into the playing field. The result of taking into possession the rebounded ball depends to a great extent on the performance of the defence players. It is essential that defence players control their part of the space to take the ball into possession before the opposing team's players since, by positioning and reacting properly in defence, players create an opportunity for a fast counter attack, and at the same time an opportunity to score as well. If the defence players do not catch the ball, transition attack is not possible, but the opposing team has a repeated attack. This is the reason why the trainers insist on players to be concentrated in defence when the ball rebounds after the goal keeper's defence. 
Rebounded balls depend to a large extent on the goal keeper's position and setting. The goal keeper is the player most essentially contributing to the result efficiency of the game (Rogulj, 2000a). Unlike other players, the goal keeper has the most immediate influence on the result of every opponents'attempt to score (Rogulj, 2009). Nowadays, shots on goal are very fast, precise, and frequently unpredictable which prevents the goal keeper from keeping the ball in the possession after a defence (Debanne, 2003). The balls rebounded from the goal keeper or from the goal frame actually present the attack peak which may turn into a counter attack if the defence players take the ball in their possession, or it may end as a counter attack if the defence players take the ball into their possession or as a repeated attack if the attack players take the ball into their possession. With regard to the situation efficiency, taking into possession the rebounded ball may bring some advantage to one or the other team, i.e. defence players or attack players, and may even lead to winning the match.

Previous researches on the situation efficiency in handball have studied efficiency in relation to playing positions (Gajić, 1970; Gruić, Vuleta, \& Milanović, 2006; Ohnjec, Vuleta, Milanović, \& Gruić, 2008), the efficiency in relation to the shooting zones (Gajić, 1970; Pokrajac, 2008; Rogulj, 2000b), and efficiency in relation to the different ways of shooting (Delija \& Šimenc, 1994; Vuleta, Milanović, \& Sertić, 2003).
Further on, there were some studies on the differences between the shooting frequency and efficiency in relation to the team's efficiency (Apitzs \& Liu, 1997; Taborsky 2008), in addition to the influence of tactics elements on the efficiency and the influence of the finalisation attack variables on the final score of the match (Rogulj, Srhoj, \& Srhoj, 2004; Rogulj \& Srhoj, 2009; Srhoj, Rogulj, \& Katić 2001). The previous researches lack in scientifically based researches studying the rebounded balls in a handball match. According to the authors' opinion, the lack of this type of research, an extremely important segment of the handball game, was the main motif for this study and for setting its main goal.

The purpose of this research was to establish the frequency of shooting from certain zones i.e. from a certain attack position, the frequency of the balls rebounded off the goal keeper or the goal frame and to determine where and who to do the performed shots rebound.

\section{METHODS}

\section{Sample of entities}

The sample of entities represents the performed shots which ended with the ball being rebounded into the playing field during the fifteen matches played by the male Croatian national handball team, eight out of which were played at the World Championship in

FIGURE 1

Shooting and rebounding zones.

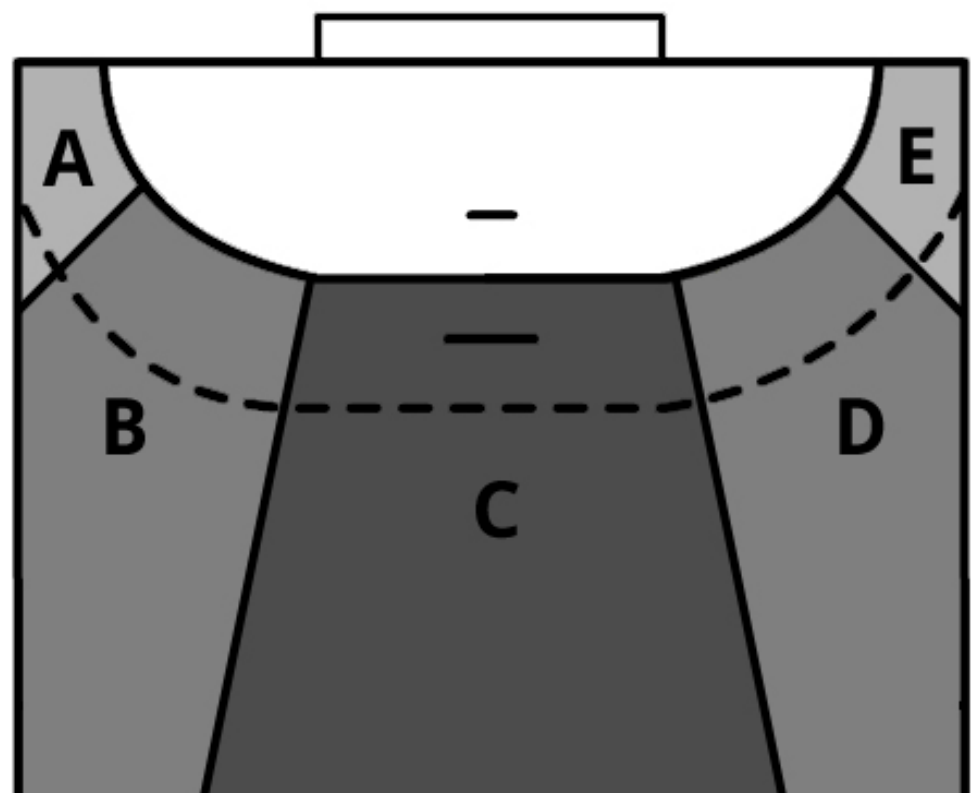

Legend: A - Left wing player's zone; B - Left back player's zone; $\mathbf{C}$ - Middle back player's zone; $\mathbf{D}$ - Right back player's zone; $\mathbf{E}$ - Right wing player's zone. 
Tunisia in 2005, and seven were played at the European championship in Austria in 2010. We analysed the attacks, i.e. the defences of the both teams in the game.

\section{Sample of varibales}

The sample of variables is presented by: shots performed from the shooting zones, the shots rebounding into the same zones, the defence players, i.e. the attack players as the possessors of the rebounded balls (Figure 1). C zone is the widest and forms a $60^{\circ}$ angle, while the other zones $A, B, D$ and $\mathrm{E}$ form a $30^{\circ}$ angle.

\section{Statistical analysis}

Within descriptive statistics we calculated entity frequencies and the percentage proportion of entities presence in relation to a certain variable. The connection between the shooting zones and the zones where the balls rebounded to was established by a nonparametrical $\chi^{2}$ test.

\section{FIGURE 2}

Shooting and rebounding frequencies with regard to certain zones.

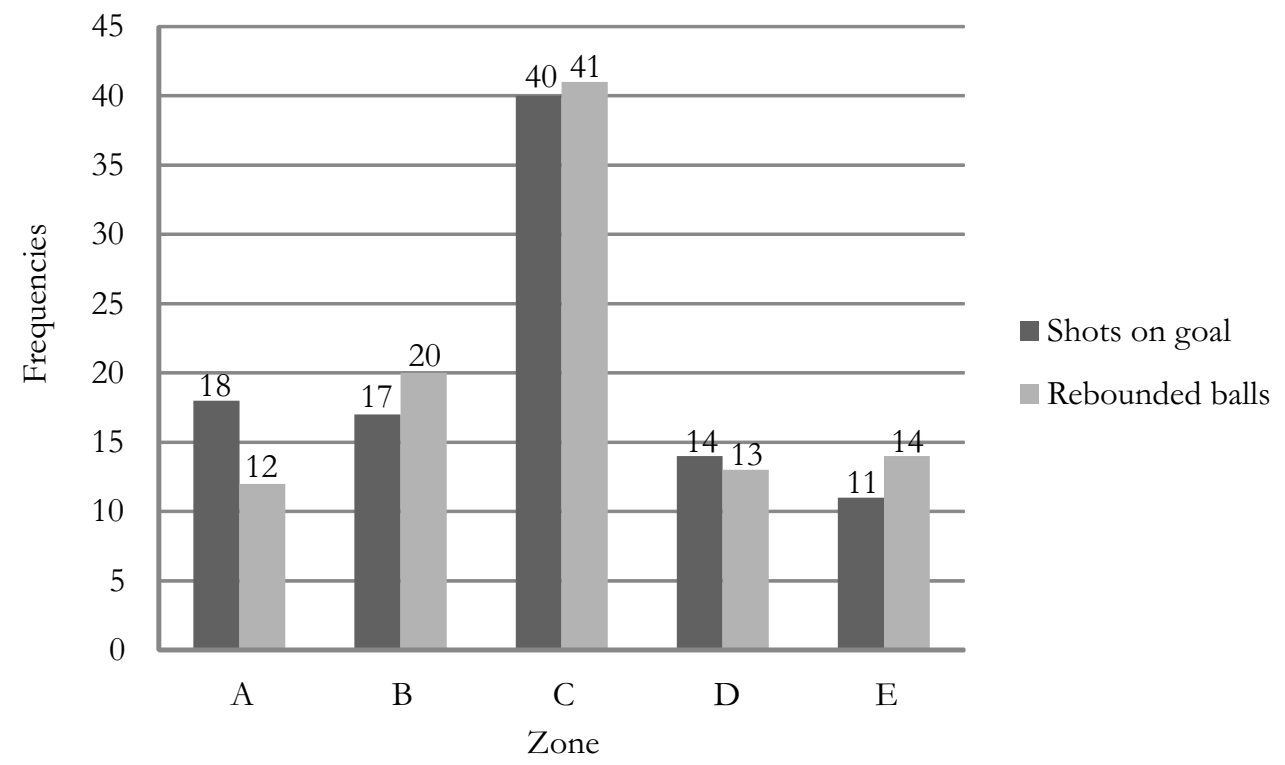

Legend: A - Left wing player's zone; B - Left back player's zone; C - Middle back player's zone; D - Right back player's zone; $\mathbf{E}$ - Right wing player's zone.

\section{RESULTS}

In the fifteen studied matches included in this research, the ball rebounded off the goal keeper or the goal post 264 times, which is, on average, the total of 17.6 rebounded balls in a match. The ball was taken into possession by the defence players 187 times $(71 \%)$ and the attack players took the ball into possession 77 times (29\%).

Figure 2 displays the shooting frequency from a certain zone as well as the frequency of balls rebounding into a certain zone. The greatest number of shots on goal was performed from the $\mathrm{C}$ zone (40\%) i.e. from the position of the middle back player and pivot. The shooting frequency from other positions is mostly equal, except for the left side of the attack $(\mathrm{A}+\mathrm{B}=35 \%)$ which prevails in relation to the right side $(\mathrm{D}+\mathrm{E}=25 \%)$.
The balls rebounded off the goal keeper or the goal frame, likewise in the performed shots, ended for the greatest number of times in the C zone (41\%) and in the B zone (20\%), while other zones had nearly equally disposed frequency.

Figure 3 displays the frequencies of the teams' ball possession in attack and defence after the balls rebounded in certain zones. The largest number of the rebounded balls is in the $C$ zone (108) and the smallest in zones A (36), D (35) and E (36). The graph displays that defence players take the ball into possession more times than the attack players.

The $\chi^{2}$ test did not determine any statistically significant differences between the frequencies of shooting and the frequency of rebounded balls with relation to the shooting zones, i.e. to the rebounding zones (table 1). This means the largest number of performed shots from a certain shooting zone returns, i.e. rebounds into the same zone. 
FIGURE 3

Frequencies of the ball possession after shooting from a certain zone.

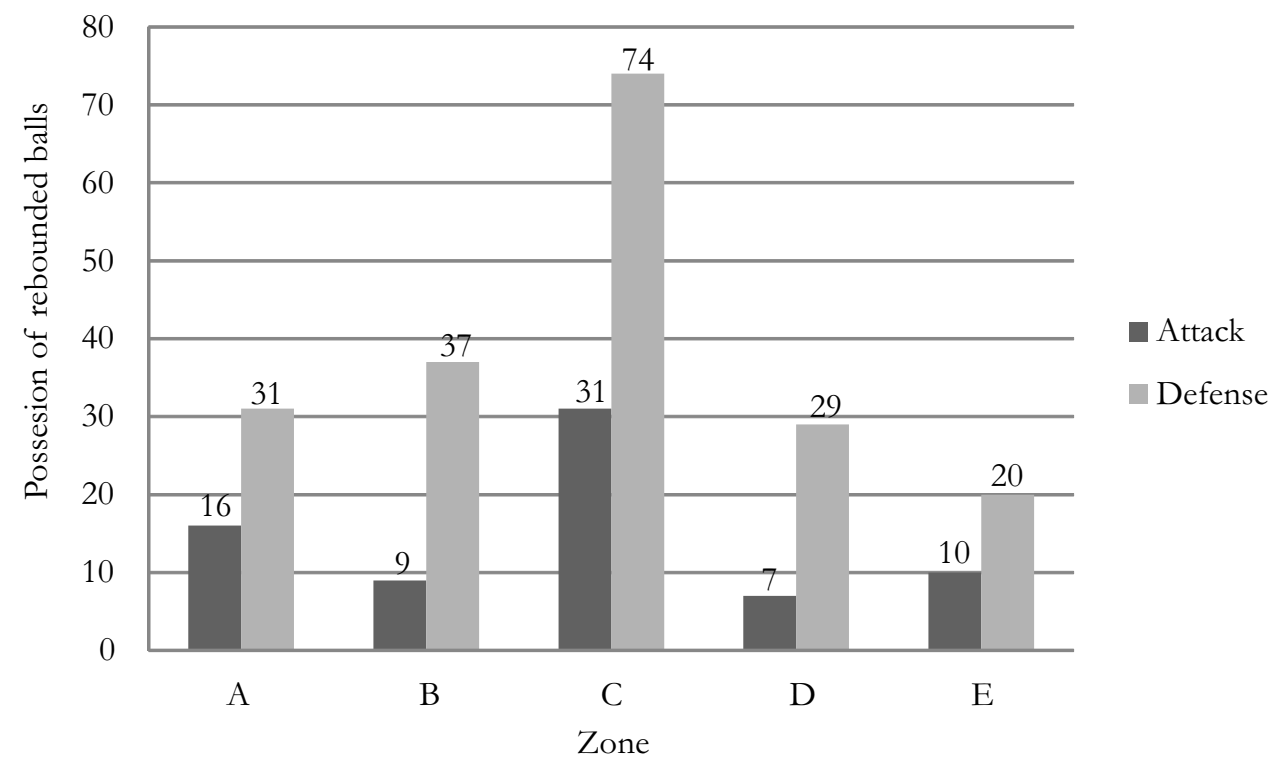

Legend: A - Left wing player's zone; B - Left back player's zone; $\mathbf{C}$ - Middle back player's zone; D - Right back player's zone; $\mathbf{E}$ - Right wing player's zone.

\section{TABLE 1}

Connection of frequencies of performed shots and rebounded balls in certain zones.

\begin{tabular}{lccccc}
\hline \multicolumn{1}{c}{ Zones } & A & B & C & D & E \\
\hline Directed balls & 47 & 46 & 105 & 36 & 30 \\
\hline Rebounded balls & 31 & 54 & 108 & 35 & 36 \\
\hline$\chi^{2}=4.52 ; d f=4 ; p^{>} .05$ & & & & &
\end{tabular}

Legend: A - Left wing player's zone; $\mathbf{B}$ - Left back player's zone; $\mathbf{C}$ - Middle back player's zone; $\mathbf{D}$ - Right back player's zone; $\mathbf{E}$ - Right wing player's zone; $\chi^{2}$ - Chi-sequer test; $d f$ - Degrees of freedom; $p$ - Probability.

\section{DISCUSSION}

The reason for a significantly large number of rebounded balls in the possession of defence players could be found in the distance in relation to the rebounded ball of the defence and attack players. The defence players are in a more favourable position, and also, by proper blocking, have a better opportunity to ensure a more favourable position to receive the ball rebounded from an attack player.

The largest number of shots performed from the $\mathrm{C}$ zone may be explained by the width of the zone which has the largest surface. This is the zone where two players move, the middle back player and the pivot and where most of the actions end since, to the players, from a geometrical point of view, the goal here is the widest (Gajić 1970). Seven-metre penalty shot is also performed from the centre of this zone. Due to tactics reasons, the ball is most frequently here, in this zone. Most of the attacks start with the middle back player as the game organiser and the distribution of the ball from one wing player to another is always performed over the centre of the attack. All this explains for the largest shooting frequency $(40 \%)$ from the centre zone of the position attack.

Figure 3 evidently shows that after shooting most balls return to the central zone and, with a slightly smaller frequency, to the zone of the back player on the left side of the attack. The player performing the shot always attempts to shoot through an angle as wide as possible in relation to the goal, in a straight line if the situation is allowing it. In theory, the greatest efficiency is achieved from the central position. Due to this straight or approximately straight shooting, in most cases, the ball rebounds back into the $\mathrm{C}$ zone, and we have previously established that most shots were performed from this zone. The results are logical and based on the basic laws of physics, i.e. on 
the mechanics of collision between the elastic and solid substances (Robertson, Caldwell, Hamill, Kamen, \& Whittlesey, 2004 2004).

Although the defence players dominate in the possession of balls in all the zones, a certain number of the rebounded balls are still taken in the possession by the attack players. The pivot has a major role here since he can take the rebounded ball into the possession by the means of his blocking and positioning on the line. There is a similar situation in wing positions where the last defenders by prematurely starting the counter attack, enable the wing players to take the ball into their possession.

In the largest number of cases the ball returns to the same zone from which the shot was performed. This fact can be easily explained by the basic laws of physics (Ivančević, Jovanović, Đukić, Marković, \& Đukić, 2008) and creates the basis to understand the rebounding of the ball in the handball game, based on which we can and precisely and with quality organise the training programme depending on the characteristic situations.

\section{CONCLUSION}

Based on the conducted analyses and obtained results, we may form several conclusions. The largest frequency of shooting on goal comes from the central zone which is the consequence of the space width, more players playing in the same zone, the greatest circulation of ball, performance of the penalty shots and the position of the zone in relation to the goal frame.

The rebounding of the ball off the goal keeper or the goal frame depends on a large number of factors, but mostly on the starting point of the ball (the angle of shooting) and the positioning of the goal keeper in relation to the goal. The results have shown that in the $40 \%$ of the cases the ball rebounded into the centre part of the court. Nowadays, shots on goal are very fast and precise, so the goal keeper rarely remains in the possession of the ball after having defended the shot. Defence players prevail in the possession of the rebounded balls which is not surprising considering the vicinity of defence players, i.e. the distance of the attack players in relation to the rebounded ball.

In the largest number of cases, the ball returns to the zone from where the shot was performed, thus during the training procedure, more time should be given to practising this segment of the game, which is most frequently not the case in practice, according to the authors' opinion and experience. The results of the research may be used in the tactical preparation of the match by giving certain defence players concrete tasks to start the counter attack with relation to the positions from which the attack players performs the shot on goal.

The research also revealed that rebounded balls are quite frequent in matches and more time should be spent on practising the phase of taking the rebounded ball into possession.

Handball is a complex game where all the segments of the game can hardly be controlled with the same quality. However, the proper players' reaction in characteristic situations may bring an advantage or a victory to a certain team. Thus, it is important in further analysis and training procedures in top quality handball to give more attention to the details such as rebounded balls and taking it into possession.

\section{REFERENCES}

Apitzs, E., \& Liu, W. H. (1997). Correlation between field dependence-independance and handball shooting by Swedish national male players. Perceptual and Motor Skills, 84, 13951398. doi: 10.2466/pms.1997.84.3c.1395

Debanne, T. (2003). Perceptive and decisional activity of goalkeeper during his parade's action: Experts skills. STAPS, 62(3), 43-58. doi: $10.3917 /$ sta.062.0043

Delija, K., \& Šimenc, Z. (1994). Utjecaj nekih općih i situacijskih motoričkih sposobnosti i znanja na uspjeh u rukometu [Impact of the general and situational motor skills and knowledge to succeed in handball]. Kinezilogija, 26, 51-54.

Gajić, V. (1970). Analiza VII. prvenstva sveta u rukometu. Sportska praksa.

Gorostiaga, E. M., Granados, C., Ibáñez, J., \& Izquierdo, M. (2005). Differences in physical fitness and throwing velocity among elite and amateur male handball players. International Journal of Sports Medicine, 26(3), 225-232. doi: 10.1055/s-2004-820974; PMid: 15776339

Gruić, I., Vuleta, D., \& Milanović, D. (2006): Performance indicators of teams at the 2003 men's world handball championship in Portugal. Kinesiology, 38(2), 164-175

Hermassi, S., Chelly, M. S., Fathloun, M., \& Shephard, R.J. (2010). The effect of heavy-vs. moderate-load training on the development of strength, power, and throwing ball velocity in male handball players. Journal of Strength and Conditioning Research, 24(9), 2408-2418. doi: 10.1519/JSC.0b013e3181e58d7c; PMid: 20706155 
Ivančević, T, Jovanović, B., Đukić, M., Marković, S., \& Đukić, N. (2008). Biomechanical analysis of shots and ball motion in tennis and the analogy with handball throws. Facta Universitatis, Physical Education and Sport, 6(1), 51-66.

Ohnjec, K., Vuleta, D., Milanović, D., \& Gruić, I. (2008). Performance indicators of teams at the 2003 world handball championship for women in croatia. Kinesiology, 40(1), 69-79.

Pokrajac, B. (2008). EHF Men's Euro 2008 Analysis, discussion, comparison, tendencies in modern handball. EHF Periodical. PMCid: 267037

Robertson, G., Caldwell, G., Hamill, J., Kamen, G., \& Whittlesey, S. (2004). Research Methods in Biomechanics. Champaign, IL: Human Kinetics.

Rogulj, N. (2000a). Tebnika, taktika $i$ trening vratara $u$ rukometu [Technique, tactics and practice goalkeepers in handball]. Split, HR: Fakultet prirodoslovno-matematičkih znanosti i odgojnih područja u Splitu.

Rogulj, N. (2000b). Differences in situation-related indicators of handball game in relation to the achieved competitive results of the teams at 1999 World Championship in Egypt. Kinesiology, 32(2), 63-74.
Rogulj, N. (2009). Modeli taktike u rukometu [Models of handball tactics]. Split, HR: Znanstvenosportsko društvo Grifon.

Rogulj, N., \& Srhoj, V. (2009). Influence of the collective attack tactics on handball match outcome. Fizička kultura, 37, 15-20

Rogulj, N., Srhoj, V., \& Srhoj, Lj., (2004). The contribution of collective attack tactics in differentiating handball score efficiency. Collegium Antropologicum, 28(2), 739-746

Srhoj, V., Rogulj, N., \& Katić, R. (2001). Influence of the attack end conduction on match result in handball. Collegium Antropologicum, 25(2), 611617.

Taborsky, F. (2008). Cumulative indicators of team playing performance in handball (Olympic Games Tournaments 2008). Retrived from http//www.eurohandball.com.

Vuleta, D., Milanović, D., \& Sertić, H. (2003). Povezanost varijabli šutiranja na gol s konačnim rezultatom rukometnih utakmica Europskog prvenstva 2000. godine za muškarce [Relationship between variables shooting on goal with the final result handball match on the European Championship for men 2000]. Kinesiology, 35(2), 168-183.

Received: November 14, 2012

Revision received: Jun 1, 2013

Accepted: Jun 19, 2013

Correspondence to:

Nikola Foretić, PhD

Tijardovićeva 12, 21000 Split, Croatia

Phone: 0038598666136 E-mail: nikolaforetic@hotmail.com 